\title{
Pemanfaatan Aplikasi Quizizz sebagai Media Penilaian Pembelajaran Ilmu Pengetahuan Alam
}

\author{
Dhian Nuri Rahmawati ${ }^{1}$, Ana Fitrotun Nisa ${ }^{2}$, Dwi Astuti ${ }^{3}$, \\ Fajariyani $^{4}$, \& Suliyanti ${ }^{5}$ \\ Universitas Sarjanawiyata Tamansiswa Yogyakarta \\ Email: ${ }^{1}$ dhianrahma69@gmail.com, ${ }^{2}$ ananisa@ymail.com, \\ 3wwiastuti@gmail.com, ${ }^{4}$ fajariyani@ymail.com, ${ }^{5}$ suliyanti@ymail.com
}

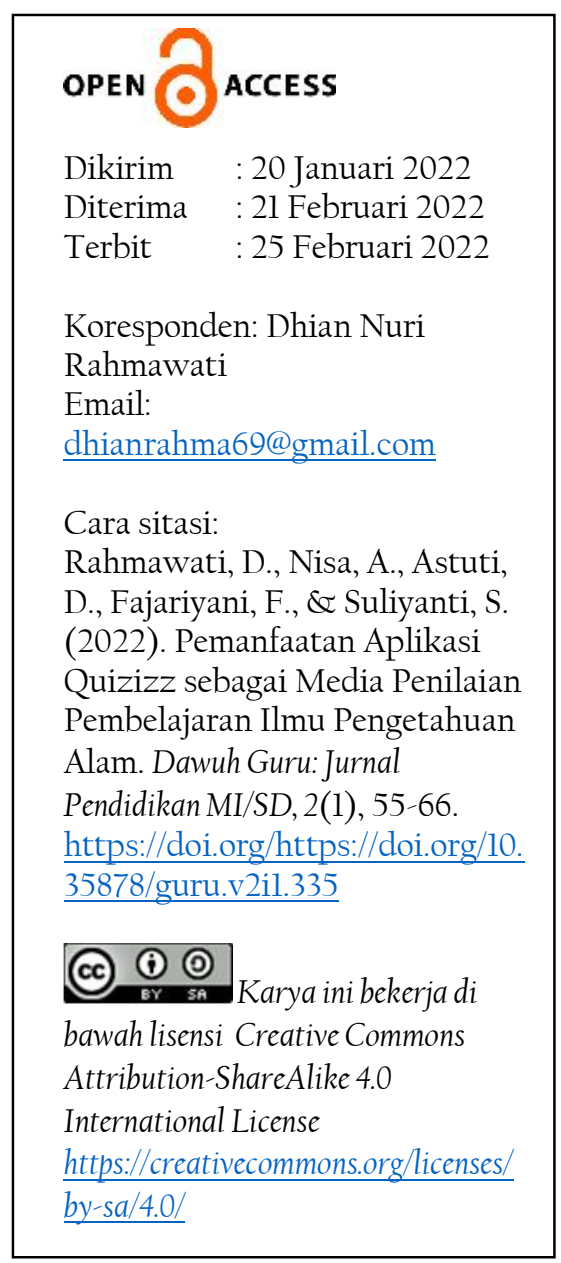

\begin{abstract}
The learning assessment process of students is an important component in an effort to obtain learning achievement information. The utilization of technology (computing) makes this process more effective. Quizizz becomes one of the platforms that are expected to attract interest, and add to student concentration. This study uses qualitative descriptive methods to describe the interest conditions and concentration of grade VI students at SDN Banjarharjo. This study uses various insturmen to collect data (1) obeservation sheets, (2) questionnaires / questionnaires of student responses; (3) interview guidelines as a support for the results of the student response questionnaire. The results of the study provide an idea that the Quizizz application can increase students' interest and concentration in working on research problems to achieve maximum results.
\end{abstract}

Keyword: Assessment Activities; Quizizz; Interests; Concentration

\begin{abstract}
Abstrak
Proses penilaian belajar siswa merupakan komponen penting sebagai upaya memperoleh informasi capaian pembelajaran. Pemanfaatan teknologi (komputasi) membuat proses ini lebih efektif. Quizizz menjadi salah satu platform yang diharapkan mampu menarik
\end{abstract} minat, dan menambah konsenterasi siswa. Penelitian ini menggunakan metode deskriptif kualitatif untuk menggambarkan kondisi minat dan konsentrasi belajar siswa kelas VI di SDN Banjarharjo. Penelitian ini menggunakan berbagai insturmen untuk mengumpulkan data (1) lembar obeservasi, (2) kuesioner/angket 
respon peserta didik; (3) lembar pedoman wawancara sebagai pendukung hasil kuesioner respon peserta didik. Hasil penelitian memberikan gambaran bahwa aplikasi Quizizz dapat meningkatkan minat dan konsentrasi siswa dalam mengerjakan soal penailian untuk mencapai hasil yang maksimal.

Kata kunci: Kegiatan Penialain; Quizizz; Minat; Konsentarsi

\section{A. Pendahuluan}

Pendidikan dan kurikulum merupakan dua hal yang saling berkaitan. Pendidikan sangat membutuhkan kurikulum agar mampu mengembangkan potensi siswa sehingga mampu memecahkan masalah pada kehidupan yang dihadapi. Hal ini sesuai dengan Undang-Undang Nomor 20 Tahun 2003 tentang Sistem Pendidikan Nasional menyebutkan bahwa pendidikan nasional berfungsi untukmengembangkan kemampuan dan membentuk watak serta peradaban bangsa yang bermartabat dalam rangka mencerdaskan kehidupan bangsa.

Menurut (Daryanto, 2014) kurikulum merupakan suatu respon pendidikan terhadap kebutuhan masyarakat dan bangsa dalam membangun generasi muda bangsanya. Dalam menjalankan suatu kurikulum terdapat suatu perangkat pembelajaran yang berguna sebagai acuan dalam pelaksanaan kurikulum tersebut. Perangkat pembelajaran merupakan suatu perencanaan yang dipergunakan dalam proses pembelajaran. Oleh karena itu, (Kunandar, 2014) menjelaskan bahwa "setiap guru pada satuan pendidikan berkewajiban menyusun perangkat pembelajaran yang lengkap, sistematis agar pembelajaran dapat berlangsung secara interaktif, inspiratif, menyenangkan, menantang, memotivasi siswa untuk berpatisipasi aktif". Ibrahim dalam (Trianto, 2007) menyatakan bahwa "perangkat pembelajaran yang diperlukan dalam mengelola proses belajar mengajar dapat berupa silabus, RPP, Lembar Kegiatan Siswa (LKS), Instrumen Penaialian atau Tes Hasil Belajar, serta Media Alat Peraga pembelajaran".

Kegiatan penilaian siswa merupakan komponen penting di dalam kegiatan belajar mengajar di sekolah. Untuk memperoleh informasi tentang pencapaian hasil dari proses pembelajaran siswa sesuai dengan tujuan yang telah ditetapkan, maka dibutuhkan penilaian hasil belajar. Menurut (Wahidmurni, Mustikawan, \& Ridho, 2010) fungsi penting bagi pendidik dalam mengevaluasi belajar siswa adalah memberikan umpan balik kepada siswa dalam mempertimbangkan efektivitas dan efisiensi dari proses pembelajaran yang dilakukan. (Miller, Linn, \& Gronlund, 2012) mendefinisikan penilaian belajar siswa sebagai berbagai prosedur untuk memperoleh informasi belajar siswa dan menentukan keputusan berkaitan dengan kinerja atau hasil belajar siswa. Penilaian hasil belajar siswa merupakan kegiatan guru yang berkaitan dengan pengambilan keputusan tentang pencapaian kompetensi atau hasil belajar siswa 
selama mengikuti proses pembelajaran.

Data penilaian siswa yang dikumpulkan guru melalui prosedur dan alat penilaian yang sesuai dengan kompetensi yang harus dicapai oleh siswa atau indikator-indikator yang telah ditentukan untuk dinilai. Alat penilaian hasil belajar dapat memanfaatkan teknologi yang berkembang saat ini dimana penilaian hasil belajar siswa akan lebih cepat menggunakan mesin (komputasi), menjangkau segala pekerjaan rutin (otomatisasi), dan komunikasi dilakukan dari mana saja dan kapan saja.

Berdasarkan hasil dari wawancara dan observasi yang peneliti lakukan pada guru kelas di SD Negeri Banjarharjo pada tanggal 5 November 2021, diketahui bahwa guru di sekolah belum optimal dalam pemanfaatan sarana media TIK meskipun di sekolah ada beberapa unit laptop dan tersedianya jaringan internet yang bisa digunakan untuk guru dalam menunjang proses pembelajaran. Guru kurang mendapatkan pembekalan mengenai pembelajaran inovatif terutama dalam menggunakan dan membuat media pembelajaran dan juga penialian.

Selama ini pelatihan yang wajib diikuti guru berkenaan dengan implementasi Kurikulum 2013, penyususnan RPP, dan macam-macam penailaian dalam Kurikulum 2013. Sementara pelatihan yang berupa menafaatan aplikasi pembelajaran maupun aplikasi penialian yang banyak ditawarkan di berbagai media sosial sifatnya sukarela. Sedangkan jika tidak ada keharusan biasanya para guru enggan mengikuti karena dianggap sulit dan takut nantinya ada tugas pengaplikasian. Guru tidak dapat meninggalkan sistem ceramah saat proses pembelajaran berlangsung sehingga membuat siswa pasif saat proses pembelajaran berlangsung.

Terkait dengan penilaian, selama ini guru melakukan penilaian hasil belajar atau tes hasil belajar siswa menggunakan cara konvensional yaitu berbasis kertas (paper based test). Kelemahan paper based test atau paper and pencil test diantaranya pengadaan logistik berupa kertas dan penggandaan soal memerlukan biaya yang cukup besar dan kurang ekonomis. Selain itu, soal hasil dari pencetakan atau fotokopi terkadang masih ada yang kualitasnya rendah, kurang menarik, buram, dan tulisan yang kurang jelas akibat dari buruknya kualitas fotokopi atau kesalahan teknis dalam penggandaan soal. $\mathrm{Hal}$ ini tentu akan menyulitkan siswa dalam membaca soal dan membuat siwa jenuh dalam mengerjakan soal. Umumnya siswa mengerjakan soal sambil bermain, bercerita dengan teman dan aktifitas akitifitas lain yang membuat tidak fokus pada apa yang seharsnya dilakukan, sehingga menghabiskan waktu pemebalajaran. Guru juga membutuhkan waktu yang cukup lama dalam mengoreksi jawaban siswa yang dilakukan secara manual sehingga penilaian siswa tersebut tidak dapat langsung diketahui hasilnya.

Pada era saat ini semua telah menggunakan peralatan dan media yang 
berbasis digital, tak terkecuali dalam bidang pendidikan. Guru dituntut mengikuti tantangan pembelajaran berbasis digital,seiring dengan berkembangnya Teknologi dan Informasi. Sehingga diharapkan dapat memanfaatkan media pembelajaran berbasis digital yang inovatif, efektif, dan efisien dalam upaya meningkatkan hasil belajar siswa. Banyak media pembelajaran digital yang telah disuguhkan, yang bisa diterapkan oleh guru, salah satunya yaitu media pembelajaran yang atraktif dan berbasis permainan. Selain media pembelajaran banyak pula tersedia applikasi untuk penilaian berbasis digital, salah satunya aplikasi Quizizz.

Quizizz merupakan aplikasi permainan pendidikan yang sifatnya naratif dan fleksibel, selain bisa dimanfaatkan sebagai sarana menyampaikan materi, Quizizz juga bisa digunakan sebagai media penialian pembelajaran yang menarik dan menyenangkan. Dengan memanfaatkan aplikasi Quizizz ini, guru dapat menciptakan atmosfer pembelajaran yang lebih hidup, sehingga dapat mencapai tujuan pembelajaran.

Materi Ilmu Pengetahuan Alam memiliki cakupan yang sangat luas. Dalam menyampaikan materi kepada siswa guru diharapkan memiliki trik agar siswa tidak merasa bosan dalam pembelajaran. Karena luasnya materi kadang siswa merasa bosan. Ketika siswa sudah merasa bosan pada pembelajaran dampaknya mereka juga merasa malas untuk mengerjakan tes evalusai hasil pemeblajaran. Oleh karena itu, diperlukan sebuah teknik penilaian hasil belajar siswa berbasis digital sebagai alternatif solusi terhadap permasalahan yang dihadapi guru. Peneliti tertarik untuk mengembangkan perangkat evaluasi atau penilaian berbasis digital sebagai media penailian pembelajaran.

\section{B. Metode Penelitian}

Pada penelitian ini, peneliti menggunakan pendekatan deskriptif kualitatif. Dengan pendekatan deskripsi kualitatif maka peneliti dapat menggambarkan kondisi minat dan konsentrasi belajar siswa kelas VI di SDN Banjarharjo. Dalam melakukan penelitian ada beberapa tahap yang harus di lakukan. Ada tiga tahap penelitian menurut (Moleong, 2017) yaitu tahap pra lapangan, tahap pekerjaan lapangan dan tahap analisis data.

Berikut adalah penjelasan dari masing-masing tahap:

1. Tahap Pra Lapangan

Pada tahap ini peneliti menetapkan subjek penelitian, yakni siswa kelas VI SDN Banjarharjo dengan jumlah siswa sebanya 19 anak. Selanjutnya peneliti memohon izin kepada kepala sekolah. Pada hari berikutnya peneliti melakukan pra observasi dan juga menyiapkan instrumen untuk penelitian. 


\section{Tahap Pekerjaan Lapangan}

Pada tahap ini peneliti mulai melakukan observasi menggunakan aplikasi penilaian berbasis digital (Quizizz) pada saat proses belajar. Peneliti mengamati minat dan konsentrasi belajar siswa ketika menggunakan apliaksi Quizizz. Peneliti menyiapkan instrumen untuk mendapatkan data berupa; (1) lembar observasi; (2) kuesioner/angket respon peserta didik; (3) lembar pedoman wawancara sebagai pendukung hasil kuesioner respon peserta didik.

3. Tahap Analisis

Data yang sudah didapatkan melalui observasi, wawancara dan juga angket akan dianalisis sesuai dengan yang dibutuhkan oleh peneliti untuk melengkapi penelitiannya.

Pada penelitian ini, peneliti menggunakan observasi terus terang atau tersamar dikarenakan dengan menggunakan observasi terus terang atau tersamar maka subjek yang diteliti akan mengetahui bahwa peneliti sedang mengadakan penelitian. Namun, peneliti tetap menjaga rahasia dalam penelitiannya dengan cara tidak memberitahu apa yang akan diteliti sehingga hasil dari observasi tersebut murni dan tidak di buat-buat. Sebelum melakukan penelitian, peneliti melakukan pra observasi terlebih dahulu untuk mengetahui sejauh mana minat dan konsentrasi belajar siswa di kelas VI.

Instrumen berikutnya yaitu pedoman angket/kuisoner. Angket digunakan untuk melihat persepsi siswa, yaitu alat bantu yang digunakan peneliti untuk mengumpulkan data berupa seperangkat pertanyaan atau pernyataan tertulis yang harus dijawab oleh responden (Sugiyono, 2016). Angket terdiri atas 10 pernyataan yang sudah disesuaikan dengan indikator minat dan konsentrasi belajar siswa. Untuk mengolah data yang diperoleh dari angket dalam bentuk skor yang dianalisis menggunakan skala likert.

Untuk memperoleh persentase skor angket membandingkan dengan jumlah keseluruhan jawaban yang diberikan oleh responden dengan skor maksimal, kemudian dikali $100 \%$. Adapun rumusnya sebagai berikut.

$$
\begin{aligned}
& \mathrm{P}=\frac{\Sigma R}{N} \times 100 \% \\
& \text { Keterangan: } \\
& \mathrm{P} \quad=\text { Presentase skor masing-masing responden } \\
& \begin{array}{l}
\sum R \quad=\text { Jumlah keseluruhan skor jawaban yang diberikan responden } \\
N=\text { Skor maksimal atau ideal }
\end{array}
\end{aligned}
$$


Tabel 1.

Konversi Kriteria Interpretasi

\begin{tabular}{|c|c|c|}
\hline No. & $\begin{array}{c}\text { Tingkat Pencapaian } \\
\mathbf{( \% )}\end{array}$ & Kualifikasi \\
\hline 1 & $80-100 \%$ & Sangat Baik \\
\hline 2 & $60-79,99 \%$ & Baik \\
\hline 3 & $40-69,99 \%$ & Cukup \\
\hline 4 & $20-39,99 \%$ & Kurang \\
\hline 5 & $0-19,99 \%$ & Sangat Kurang \\
\hline
\end{tabular}

(Sumber: Tegeh \& Kirna, 2010).

Instrumen berikutnya yaitu wawancara. Wawancara merupakan teknik dalam mencari informasi dengan cara melakukan percakapan dengan informan. Pada penelitian ini, peneliti menggunakan wawancara semi terstruktur dikarenakan wawancara yang dilakukan akan lebih terbuka dan bisa menerima masukan dari informan. Beberapa pertanyaan-pertanyaan yang akan diajukan juga kondisional, tergantung dengan jawaban dari yang terwawancara sebelumnya.

\section{Hasil dan Pembahasan}

\section{Pemanfaatan Aplikasi Quizizz}

Pemanfaatan media digital sebagai pembelajaran sudah mengalami pengembangan yang signifikan. Hadirnya media digital ini memberikan beragam inovasi pedidikan, dimana pembelajaran dan penilaian kovensional yang kaku dan monoton akan digantikan dengan pembelajaran mengunakan media digital yang dianggap lebih praktis, fleksibel, tidak dibatasi oleh ruang dan waktu. Media pembelajaran yang tepat menjadi satu hal penting demi menunjang keberhasilan pendidikan. Berperannya media pembelajaran sebagai wadah penyampaian pesan pembelajaran kepada sasaran pembelajaran. Hal ini di atur penuh oleh guru, guna menilai dan menimbang perkembangan pembelajaran.

Semakin cepatnya arus globalisasi, memunculkan pula arus lain dalam perkembangan teknologi, yang akhirnya lahir aplikasi Quizizz sebagai media pembelajaran, penunjang keberlangsungan kegiatan belajar mengajar ditengah pandemi. Aplikasi Quizizz bersifat online, yang artinya dapat digunakan dengan mudah jika didukung dengan akses internet yang memadai. Aplikasi Quizizz memiliki kelebihan-kelebihan yang dapat dengan mudah di manfaatkan selain media pembelajaran, juga bahan evaluasi pembelajaran, sebagai contoh, terdapat data dan perhitungan statistik kinerja siswa, yang hasilnya bisa menggambarkan sejauh mana pemahaman siswa terhadap materi, nantinya menjadi bahan ukur evaluasi pembelajaran secara keseluruhan.Sehingga, memberikan warna baru terhadap olah evaluasi guru dan pola pembelajaran yang menyenangkan bagi siswa-siswi. 
Selanjutnya pada tahap pelaksanaan diperoleh hasil sebagaimana terlihat dalam tabel berikut:

Tabel 2.

Persentase Skor Hasil Indikator Minat

\begin{tabular}{|l|c|c|c|c|c|}
\hline \multicolumn{1}{|c|}{ Indikator } & \multicolumn{5}{c|}{ Keterangan } \\
\hline Indikator Minat & STS & TS & KS & S & SS \\
\hline Saya merasa senang menggnuakan aplikasi Quizizz & & & & 9 & 1 \\
\hline $\begin{array}{l}\text { Saya tidak merasa kesuliatan dalam mengguankan } \\
\text { aplikais Quizizz }\end{array}$ & & & 1 & 8 & 1 \\
\hline $\begin{array}{l}\text { Saya lebih termotivasi dalam mengerjakan soal } \\
\text { penialain ketika mengguankan aplikasi Quizizz }\end{array}$ & & & & 8 & 2 \\
\hline $\begin{array}{l}\text { Saya bersemangat ketika mengerjakan soal dengan } \\
\text { aplikasi Quizizz }\end{array}$ & & & 8 & 2 \\
\hline $\begin{array}{l}\text { Dengan apilaski Quizizz saya memiliki rasa ingin } \\
\text { tau yang tinggi }\end{array}$ & & 1 & 7 & 2 \\
\hline Jumlah & & \multicolumn{5}{c|}{$81,6 \%$} & 160 & 40 \\
\hline Persentase & \multicolumn{5}{|c|}{ Sangat baik } \\
\hline Kualifikasi & & & & \\
\hline
\end{tabular}

Tabel 3.

Persentase Skor Hasil Indkator Konsentrasi

\begin{tabular}{|l|l|l|l|l|l|}
\hline \multicolumn{1}{|c|}{ Indikator } & \multicolumn{5}{|c|}{ Keterangan } \\
\hline Indikator Konsentrasi & STS & TS & \multicolumn{1}{|c|}{ KS } & \multicolumn{1}{|c|}{ S } & SS \\
\hline $\begin{array}{l}\text { Saya mengerjakan soal dengan fokus ketika } \\
\text { mengunakan aplikasi Quizizz }\end{array}$ & & & 3 & 7 & \\
\hline $\begin{array}{l}\text { Saya harus mengatur waktu dengan baik agar dapat } \\
\text { menjawab soal dengan cepat dan tepat }\end{array}$ & & & 1 & 8 & 1 \\
\hline $\begin{array}{l}\text { Saya bersunguh-sungguh saat menerima materi } \\
\text { agar dapat mengerjakan soal dengan baik }\end{array}$ & & & 8 & 2 \\
\hline $\begin{array}{l}\text { Saya merasa tertantang mengerjakan soal dengan } \\
\text { aplikasi Quizizz }\end{array}$ & & & 8 & 2 \\
\hline $\begin{array}{l}\text { Soal yang terdapat dalam apliaksi menambah } \\
\text { pengatahuan terhadap materi yang diajarkan }\end{array}$ & & 2 & 7 & 1 \\
\hline Jumlah & & & 18 & 152 & 30 \\
\hline Persentase & \multicolumn{5}{|c|}{ Sangat Baik } \\
\hline Kualifikasi & \multicolumn{5}{|l}{} \\
\hline
\end{tabular}

Berdasarkan hasil penelitian terhadap minat memperoleh persentase skor $81,6 \%$ dengan kualifikasi sangat baik. Sedangkan pada indikator konsentrasi memperoleh persentase skor $80 \%$ dengan kualifikasi sangat baik. Berdasarkan hasil tersebut, aplikasi Quizizz mampu meningkatkan minat dan konsentrasi belajar siswa dan juga membuat mereka merasa senang pada saat proses pembelajaran. Siswa yang biasanya kurang aktif menjadi lebih aktif dari biasanya.

Siswa antusias melakukan kegiatan belajar dengan menggunakan aplikasi Quizizz untuk penilaian hasil belajar dikarenakan cara penggunaan aplikasi tersebut mudah dan simpel sehingga cocok untuk anak SD. Ketika guru kelas memberikan contoh penggunaan aplikasi, siswa dengan cepat dan tanggap menggunakan aplikasi tersebut. Semua siswa langsung ikut mempraktekkan. Hal tersebut menjadi tanda bahwa siswa kelas VI bisa 
menggunakan aplikasi tersebut dengan baik. Kesimpulan yang dapat ditarik dari keseluruhan hasil wawancara dan angket dengan 19 siswa yang disesuaikan dengan aspek yang diamati.

Aspek pertama yang diamati yaitu minat siswa terhadap penggunaan Quizizz pada kegiatan penilaian, dengan persentase 81,6\% masuk dalam kualifiaksi sangat baik. Siswa memberikan tanggapan bahwa penggunaan Quizizz membuat mereka semakin bersemangat, merasa senang, tidak mengalami kesulitan menumbuhkan motivasi dalam mengikuti pembelajaran, serta dapat menumbuhkan rasa ingin tahu untuk mencari jawaban yang benar ketika jawaban siswa salah.

Aspek kedua yang diamati yakni konsentrasi siswa dalam penggunaan Quizizz pada kegiatan penilaian, dengan persentase $80 \%$ masuk dalam kualifiaksi sangat baik. Siswa memberikan tanggapan bahwa penggunaan media Quizizz dapat meningkatkan konsentrasi dalam mengerjakan soal. Adanya waktu pada setiap nomor dimana jika siswa menjawab benar dengan waktu yang singkat skor akan bertambah dan peringkat akan semakin naik, membuat siswa lebih fokus, semakin tertantang, memanajemn waktu sebaik-baiknya, dan memotivasi kerja otak ketika mengerjakan soal menggunakan media Quizizz.

Siswa juga memberi tanggapan bahwa Quizizz dapat meningkatkan perhatian dalam mengikuti materi pembelajaran. Siswa merasa bahwa mereka lebih bersungguh-sungguh dalam memperthatikan penjelasan guru sebelum mengerjakan soal di Quizizz, karena ingin mendapatkan hasil yang maksimal. Bahkan siswa yang biasanya sering berbicara sendiri dengan temannya ketika guru menerangkan, siswa tersebut ikut memperhatikan.

\section{Penilaian Pembelajaran IPA melalui Aplikasi Quizizz}

Salah satu cara untuk mengukur keberhasilan pembelajaran adalah melalui penilaian pembelajaran. Penilaian pembelajaran ini merupakan satu kesatuan yang tidak bisa dipisahkan dari sebuah kegiatan pembelajaran. Dalam standar proses (Permendikbud No. 22 Tahun 2016) disebutkan bahwa kegiatan guru dalam pengelolaan pembelajaran meliputi perencanaan proses pembelajaran, pelaksanaan proses pembelajaran, dan penilaian hasil pembelajaran.

Berdasarkan hal tersebut di atas, maka alasan perlunya penilaian pembelajaran dapat disebutkan: 1) Untuk mengukur keberhasilan pembelajaran yang dikelola guru; 2) Untuk mengukur tingkat keberhasilan siswa dalam mengikuti kegiatan pembelajaran; 3) Untuk memberikan umpan balik bagi siswa dan guru; 4) Untuk evaluasi diri guru dan sekolah dalam mengelola pembelajaran.

Fokus peneliti dalam penggunaan aplikasi Quizizz ini adalah sebagai media penilaian. Penggunaan Quizizz sebagai media penialaian sangat 
mudah. Kuis interaktif ini memiliki hingga 4-5 pilihan jawaban termasuk jawaban yang benar. Bisa juga ditambahkan gambar ke latar belakang pertanyaan dan menyesuaikan pengaturan pertanyaan sesuai keinginan. Bila kuis sudah jadi, dapat dibagikan kepada siswa dengan menggunakan kode 6 digit yang dihasilkan. Quizizz dapat digunakan sebagai strategi pembelajaran yang baik dan menyenangkan tanpa kehilangan esensi belajar yang sedang berlangsung. Kelebihan dari aplikasi ini antara lain:

- Bagi Guru/Pendidik, memudahkan dalam membuat soal dan bisa diedit kapan saja.

- Ketika siswa menjawab soal atau kuis dengan benar, setelah itu akan muncul berapa poin yang didapatkan dalam satu soal, juga mendapatkan ranking atau peringkat berapa dalam menjawab kuis tersebut.

- Bilamana siswa menjawab kuis tersebut salah, maka akan muncul jawaban yang benar, guna koreksi mandiri bagi siswa.

- Ketika telah dinyatakan selesai mengerjakan kuis, pada sesi akhir atau penutup, sebelumnya akan di tampilkan review question guna mencermati kembali jawaban yang telah dipilih.

Terdapat berbagai macam fitur lain yang tersedia dalam aplikasi Quizizz, yang bisa dimanfaatkan menjadi salah satu sarana Guru dalam memberikan tugas atau pekerjaan rumah. Disamping mengerjakan tugas, siswa bisa merasakan pembelajaran yang tidak terlalu berat dalam memikirkan jawaban, karena dalam aplikasi Quizizz memiliki tampilan segar dan kaya akan hal-hal yang menyenangkan. Sebuah permainan memang tidak akan lepas denga unsur kreatif, inovatif, petualangan, dan menyenangkan, yang kemudian bisa menumbuhkan motivasi positif keinginan belajar dari setiap siswa.Sehingga, dapat mewujudkan cita-cita dan tujuan pendidikan secara konkret dan rata. Astini menjelaskan dengan pemanfaatan teknologi informasi ini merupakan inovasi pendidikan untuk menjawab tantangan yang sedang terjadi untuk menjadikan sumber belajar yang lebih variatif (Astini, 2020).

Dalam kegiatan proses pembelajaran, minat/motivasi merupakan aspek yang sangat penting. Donald dalam (Soemanto, 1998) memberikan definisi minat (motivasi) sebagai suatu perubahan tenaga di dalam diri/pribadi seseorang yang ditandai oleh dorongan afektif dan reaksi-reaksi dalam usaha-usaha mencapai tujuan. Dorongan afektif tersebut terlihat nyata dalam tingkah laku manusia. minat belajar akan timbul apabila mendapatkan rangsangan dari luar. Dan kecenderungan untuk merasa tertarik pada suatu bidang bersifat menetap dan merasakan perasaan yang senang apabila ia terlibat aktif didalamnya. Berdasarkan ahsil obervasi, pengisian angket dan didukung dengan wawancara, siswa merasa senang 
ketika siswa melaksanakan penialian pembelajran dengan aplikasi Quizizz ini.

Salah satu faktor yang dapat mempengaruhi rendahnya daya pemahaman siswa adalah konsentrasi. Jika konsentrasi siswa rendah, maka akan menimbulkan aktivitas yang berkualitas rendah pula serta dapat menimbulkan ketidakseriusan dalam belajar dan daya pemahaman terhadap materi pun menjadi berkurang. Konsentrasi merupakan modal utama bagi siswa dalam menerima materi ajar serta menjadi indikator suksesnya pelaksanaan pembelajaran. Pemanfaatan aplikasi Quizizz dalam penialian pembelajaran membuat siswa merasa lebih aktif, menjadi fokus atau konsentrasi terhadap apa yang dipelajari karena merasa tertantang untuk mendapatkan hasil yang terbaik

\section{Kesimpulan}

Kesimpulan hasil penelitian bahwa perangkat penilaian berbasis digital dalam hal ini menggunakan aplikasi Quizizz mampu menumbuhkan minat dan konsentrasi belajar siswa kelas VI di SDN Banjarharjo. Terdapat berbagai macam fitur lain yang tersedia dalam aplikasi Quizizz, yang bisa dimanfaatkan. Sehingga peneliti selanjunya dapat memanafaatkan apliaksi Quizizz tidak hanya sebagai media penilaian namun juga sebagai media pembelajaran interaktif. Penggunaan Quizizz membutuhkan jaringan internet yang baik, maka penelitian ini tidak disarankan bagi sekolah/peserta didik yang berada didaerah pelosok kecuali memang sudah tersedia jaringan wifi (internet) yang cukup baik dan stabil. 


\section{Daftar Pustaka}

Setiawan, A., Wigati, S., \& Sulistyaningsih, D. (2019). Implementasi Media Game Edukasi Quizizz Untuk Meningkatkan Hasil Belajar Matematika Materi Sistem Persamaan Linear Tiga Variabel kelas X Ipa 7 SMA Negri 15 Semarang Tahun Pelajaran 2019/2020. Seminar Nasional Edusaintek FMIPA UNIMUS.

Astini, S. (2020). Pemanfaatan Teknologi Informasi dalam Pembelajaran Tingkat Sekolah Dasar pada Masa Pandemi Covid-19. Jurnal Lampuhyang. Vol. 11 No. 2

Dimyati, \& Mudjiono. (2015). Belajar dan Pembelajaran. Jakarta: Rineka Cipta

Salsabila, U. H., Habiba, I. S. ., Amanah, I. L. ., Istiqomah, N. A. ., \& Difany, S. (2020). Pemanfaatan Aplikasi Quizizz Sebagai Media Pembelajaran Ditengah Pandemi Pada Siswa SMA. Jurnal Ilmiah Ilmu Terapan Universitas Jambi $|J I I T U J|, 4(2)$, 163-173. https://doi.org/10.22437/jiituj.v4i2.11605

Imania, K.A., \& Bariah, S.K. (2019). Rancangan Pengembangan Instrumen Penilaian Berbasis Daring. Jurnal IPTEK. Vol 5 No. 1.

Aini, Y. I. (2019). Pemanfaatan Media Pembelajaran Quizizz untuk Pembelajaran Jenjang Pendidikan Dasar dan Menengah di Bengkul. Jurnal Kependidikan 2.2

Permana, I. M. J., \& Sujana, I. W. (2021). Aplikasi Pembelajaran IPS Berbasis Pendekatan Konstektual. Jurnal Penelitian dan Pengembangan Pendidikan. 5(1). Number 1

Kunandar. (2014). Penilaian Hasil Balajar Peserta didik Berdasarkan Kurikulum 2013. Jakarta: Raja Grafindo

Mulyati, S., \& Evendi, H. (2020). Pembelajaran Matematika Melalui Media Game Quizizz Unutuk Meningkatkan Hasil Belajar Matematika SMP 2 Bojonegoro. Gauss: Jurnal Pendidikan Matematika, 3(1).

Moleong, L. J. (2017). Metodologi Penelitian Kualitatif. Bandung: PT Remaja Rosdakarya.

Noor, S. (2020). Penggunaan Quizizz dalam Penilaian Pembelajaran pada Materi Ruang Lingkup Biologi untuk Meningkatkan Hasil Belajar Siswa Kelas X. 6 SMAN7 Banjarmasin. Jurnal Pendidikan Hayati, 6.(1).

Permendikbud No 22. Standar Proses Pendidikan Dasar dan Menengah, Jakarta: Peraturan Menteri dan Kabudayaan.

Gusti, A. R., Afriansari, Y., Sari, D. V., \& Walid, A. (2020). Penilaian Sikap Pembelajaran Daring IPA Terpadu dengan Menggunakan Media WhatsApp. Diffraction: Journal for Physics Education and Applied Physich. 2(2).

Rusman. (2017). Belajar dan Pembelajaran: Berorientasi Standar Proses Pendidikan. Jakarta : Kencana 
Pemanfaatan Aplikasi Quizizz sebagai Media Penilaian...

Sadiman, A. S., Rahardjo, R., Haryono, A., \& Rahardjito. (2010). Media Pendidikan. Jakarta: Pustekkom Dikbud dan PT RajaGrafindo Persada

Soemanto, W. (1998). Psikologi Pendidikan. Bandung : Rineka Cipta

Sugiyono. (2016). Metode Penelitian Pendidikan, Bandung: Alfabeta

Sukardi. (2008). Metode Penelitian Pendidikan Kompetensi dan Praktiknya. Jakarta :Bumi Aksara.

Tegeh, I. M., \& Kirna, I. M. (2010). Metode Penelitian Pengembangan Pendidikan. Universitas Pendidikan Ganesha.

Trianto. (2007). Model - model Pembelajaran inovatif berorientasi konstruktivistik. Jakarta : Prestasi Pustala

Ulhusna, M., Dewimarni, S., \& Rismaini, L. (2021). Sosialisasi Quizizz sebagi medaiPembelajaran berbasis Digital pada Masa Pandemi. Pekodimas: Jurnal Pengabdian Kepada Masyarakat, 1(2).

Wahidmurni, Mustikawan, A., \& Ridho, A. (2010). Evaluasi Pembelajaran: Kompetensi dan Praktik. Yogyakarta: Nuha litera 